\title{
Evaluating Credibility of Witnesses - \\ Are We Instructing Jurors on Invalid Factors?
}

By Aldert Vrij ${ }^{1}$ and Jeannine Turgeon ${ }^{2}$

\section{Introduction}

Jeannine Turgeon Co-author Aldert Vrij, Ph.D., an internationally respected expert on evaluating credibility and the European Consortium of Psychological Research on Deception Detection's contact person, presented an educational lecture program concerning the fallacy of considering nonverbal behavior to evaluate credibility at the 2016 Pennsylvania Conference of State Trial Judges. Many of the judges listening to Dr. Vrij, wondered - why then, do judges consistently instruct jurors to consider demeanor and other nonverbal behaviors to evaluate witnesses' credibility? Why do we ignore the overwhelming scientific evidence and continue to give jury instructions contrary to the overwhelming consensus that witness demeanor is not a basis to determine the accuracy or truthfulness of their testimony?

Many years ago, co-author Jeannine Turgeon attended United States Supreme Court Justice Sandra Day O’Connor’s lecture “Trial by Jury--In Need of Repair” at The Chautauqua Institute. Justice O'Connor criticized various aspects of our current jury system and offered suggestions for its improvement. She opined that “[j] ust because something has 'always been done' a particular way does not mean that is the best way to do it. If common sense tells us to change something, we

\footnotetext{
${ }^{1}$ Ph.D.; Professor of Applied Social Psychology, Psychology Department, University of Portsmouth, King Henry Building, King Henry 1 Street, PO1 2DY, Portsmouth, Hants, UK

2 Judge, Dauphin County Court of Common Pleas, Pennsylvania, USA, currently serves as Co-Chair of the Civil Jury Instruction Subcommittee of the Supreme Court of Pennsylvania. The Honorable Jeannine Turgeon http://www.dauphincounty.org/government/court_departments/turgeon bio.php.
} 
should change it." 3

Today therefore, it is not "common sense" that tells us that something we have always done should change, but rather that "scientific proof" tells us that something - this standard jury instruction - should change. Judges provide jurors in both civil and criminal cases various factors they should consider in deciding the truthfulness and credibility of each witness's testimony. As we have for the past century or more, judges continue to utilize standard jury instructions advising jurors to consider the witness's demeanor and other nonverbal behaviors in evaluating witness credibility.

\subsection{Existing Jury Instructions on Nonverbal Behavior and a Proposed Replacement}

Pennsylvania's criminal and civil jury instructions include the following "nonverbal behavior" factor for jurors to consider when evaluating witness credibility:

\section{How did the witness look, act, and speak while testifying? ${ }^{4}$}

Most states use similar instructions directing jurors to consider "nonverbal behavior factors" when evaluating credibility. ${ }^{5}$ An instruction from another state advises:

In determining whether to believe any witness you should use the same tests of truthfulness which you apply in your everyday lives... including the manner and appearance of the witness. ${ }^{6}$

\footnotetext{
${ }^{3}$ Justice O'Connor inspired co-author Turgeon to commence revising Pennsylvania's Supreme Court Suggested Standard Civil Jury Instructions in "Plain English," seek changes to the rules permitting jurors to take notes, to recommend judges instruct jurors on the law at the beginning as well as at the end of trial and to write a law review article discussing these necessary changes to improve our jury system. Improving Pennsylvania's Justice System Through Jury System Innovations, Jeannine Turgeon and Elizabeth A. Francis, 18 WIDENER L.J. 419 (2009).

${ }^{4} \mathrm{~Pa}$. Suggested Std. Jury Instruction (Crim.) 4.17(1)(d) "Credibility of Witnesses, General" (3rd Ed. 2016) and Pa. Suggested Std. Jury Instruction (Civil) 4.20(d") Believability of Witnesses Generally" (4th Ed., 2017 Supp.). See Appendix A for the complete Pennsylvania jury instructions on witness credibility. ${ }^{5}$ See Appendix A.

${ }^{6}$ North Carolina Pattern Jury Instruction (N.C.P.I.) Civil 101.15 (1994).
} 
Courts have been including this "nonverbal behavior" factor in jury instructions most likely because it made "common sense." However, jury instructions informing jurors they should or must consider a witness's demeanor are not supported by the current scientific research. In fact, the studies establish that rather than being a valid basis, nonverbal cues have little or nothing to do with a witness's truthfulness or credibility, as fully discussed below by co-author Vrij.

Co-author Turgeon's nearly three (3) decades as a trial judge have taught her that in nearly every civil and criminal jury trial, jurors based their verdict upon their credibility determinations. Current peer reviewed cognitive psychological studies consistently show that most courts' standard jury instructions focusing on witness demeanor are simply flawed and wrong, based upon myth rather than evidence. Now, without further delay, the legal community must revise instructions that direct jurors to evaluate a witness's nonverbal behavior without any guidance as to how to do so. Instead, we should craft new instructions on this issue, reflecting current knowledge, in order to more adequately explain to jurors that nonverbal behavior is unrelated to a witness's truthfulness or credibility. The following proposed jury instruction would accomplish this end:

When considering whether to believe a witness, many people think that how the witness behaves reveals whether he or she is being deceptive or truthful. Research shows, however, that most people, including experts, are not very good at correctly deciding whether a witness is truthful based upon how the witness looks or acts, as opposed to what he or she says. In fact, research shows little difference between the demeanor of deceptive and truthful people.

Keep this in mind when considering non-verbal behavior by a witness; that is, such behavior is an unreliable indicator of deception or truthfulness. The types of nonverbal factors you may encounter include a witness who averts his or her gaze (or looks others in the eye), shifts in his or her seat (or remains still), appears nervous or anxious (or calm), and speaks quickly (or slowly). You should IGNORE these kinds of factors as they are UNRELIABLE indicators of deception (or truthfulness). 


\section{Nonverbal Behavior and Deceit}

\section{Aldert Vrij}

Throughout history, most people assumed that lying is accompanied by specific nonverbal behaviors. The underlying assumption was that the fear of being detected was an essential element of deception. ${ }^{7}$ A Hindu writing from 900 B. C. mentioned that liars rub the great toe along the ground and shiver and that they rub the roots of their hair with their fingers. ${ }^{8}$ Münsterberg ${ }^{9}$ described the utility of observing posture, eye movements, and knee jerks for lie detection purposes. ${ }^{10}$ The well-known Austrian neurologist Sigmund Freud, father of the psychoanalysis but not a deception researcher, also expressed his view about the topic "He who has eyes to see and ears to hear may convince himself that no mortal can keep a secret. If his lips are silent, he chatters with his finger-tips; betrayal oozes out of him at every pore." 11

The belief that nonverbal behavior is revealing about deception is still widespread. In the Netherlands and United Kingdom, 75\% of the police officers who took part in a survey believed that liars 'look away and make grooming gestures. ${ }^{12}$ A worldwide survey amongst laypersons carried out in 58 different countries found that $64 \%$ thought that liars look away and that $25 \%$

\footnotetext{
${ }^{7}$ Trovillo, P. V. (1939a). A history of lie detection, I. Journal of Criminal Law and Criminology, 29, 848-881.

${ }^{8}$ Trovillo, P. V. (1939a). A history of lie detection, I. Journal of Criminal Law and Criminology, 29, 848-881.

${ }^{9}$ Münsterberg, H. (1908). On the witness stand: Essays on psychology and crime. New York: Doubleday.

${ }^{10}$ Trovillo, P. V. (1939b). A history of lie detection, II. Journal of Criminal Law and Criminology, 30, 104119.

${ }^{11}$ Freud, S. (1959). Collected papers. New York: Basic Books. (Quote appears on page 94).

${ }^{12}$ Vrij, A., \& Semin, G. R. (1996). Lie experts' beliefs about nonverbal indicators of deception. Journal of Nonverbal Behavior, 20, 65-80. Doi: 10.1007/ BF02248715; Mann, S., Vrij, A., \& Bull, R. (2004). Detecting true lies: Police officers' ability to detect deceit. Journal of Applied Psychology, 89, 137-149. Doi: 10.1037/0021-9010.89.1.137
} 
thought that liars display an increase in movements. ${ }^{13}$ Gaze aversion was the most frequently mentioned belief in 51 out of 58 countries. It showed the lowest prevalence in the United Arab Emirates, where it still was mentioned by $20 \%$ of the participants, making it the eighth strongest belief in that country.

There are numerous articles in popular magazines expressing the idea that nonverbal behavior is revealing about deception, so does the popular TV series 'Lie to Me' where the lead character Dr. Cal Lightman and his colleagues solve crimes by interpreting facial microexpressions of emotion and involuntary behaviors. There are many books conveying the idea that nonverbal behaviors are revealing of deception including (e.g., Lie spotting ${ }^{14}$ and Spy the Lie ${ }^{15}$ and (American) police manuals typically pay considerably more attention to nonverbal cues to deceit than to verbal cues (see Vrij and Granhag ${ }^{16}$ for an overview of such manuals). Nonverbal lie detection tools such as the Behavior Analysis Interview ${ }^{17}$ and Ekman's ${ }^{18}$ approach of

${ }^{13}$ The Global Deception Team (2006). A world of lies. Journal of Cross-Cultural Psychology, 37, 60-74. Doi: $10.1177 / 0022022105282295$

${ }^{14}$ Meyer, P. (2010). Lie spotting: Proven techniques to detect deception. St. Martin’s Press, New York.

${ }^{15}$ Houston, P., Floyd, M., \& Carnicero, S. (2012). Spy the lie. St. Martin’s Press, New York.

${ }^{16}$ Vrij, A., \& Granhag, P. A. (2007). Interviewing to detect deception. In S. A. Christianson (Ed.), Offenders' memories of violent crimes (pp. 279-304). Chichester, England: John Wiley \& Sons, Ltd.

${ }^{17}$ Horvath, F., Blair, J. P., \& Buckley, J. P. (2008). The Behavioral Analysis Interview: Clarifying the practice, theory and understanding of its use and effectiveness. International Journal of Police Science and Management, 10, 101-118.; Horvath, F., Jayne, B., \& Buckley, J. (1994). Differentiation of truthful and deceptive criminal suspects in behavioral analysis interviews. Journal of Forensic Sciences, 39, 793-807.

${ }^{18}$ Ekman, P. (1985). Telling lies: Clues to deceit in the marketplace, politics and marriage. New York: W. W. Norton. (Reprinted in 1992, 2001 and 2009). 
observing facial expressions and involuntary body language were frequently taught to practitioners.

\subsection{Research Into the Relationship Between Nonverbal Behavior and Deceit}

Research findings shed a pessimistic light on the relationship between nonverbal behavior and deception. In recent years, meta-analyses -articles summarizing the published research studies in a certain area- have concluded that nonverbal cues to deceit are faint and unreliable. ${ }^{19}$ For example, DePaulo et al. ${ }^{\prime 20}$ meta-analysis included 116 deception studies. Different deception studies examined various nonverbal cues including 32 nonverbal cues in six or more deception studies. Of these 32 cues, six (19\%) showed a real difference between truth tellers and liars, albeit barely perceptible. In fact, the difference between truth tellers and liars for these six cues was, on average, the equivalent of the difference in height between 15- and 16year-old girls. Who could argue that determining whether a girl is 15 or 16 years old solely based on her height is a reliable and sensible thing to do?

Research examining people's ability to detect deceit by observing other people's behavior shows an equally bleak picture. Bond and DePaulo ${ }^{21}$ published a meta-analysis about

${ }^{19}$ DePaulo, B. M., Lindsay, J. L., Malone, B. E., Muhlenbruck, L., Charlton, K., \& Cooper, H. (2003). Cues to deception. Psychological Bulletin, 129, 74-118. Doi: 10.1037/0033-2909.129.1.74; Sporer, S. L., \& Schwandt, B. (2007). Moderators of nonverbal indicators of deception: A meta-analytic synthesis. Psychology, Public Policy, and Law, 13, 1-34 Doi:10.1037/1076-8971.13.1.1; Vrij, A., Hartwig, M., \& Granhag, P. A. (2018). Reading lies: Nonverbal communication and deception. Annual Review of Psychology. Doi: 10.1146/annurev-psych-010418-103135

${ }^{20}$ DePaulo, B. M., Lindsay, J. L., Malone, B. E., Muhlenbruck, L., Charlton, K., \& Cooper, H. (2003). Cues to deception. Psychological Bulletin, 129, 74-118. Doi: 10.1037/0033-2909.129.1.74

${ }^{21}$ Bond, C. F., \& DePaulo, B. M. (2006). Accuracy of deception judgements. Personality and Social Psychology Review, 10, 214-234. Doi: 10.1207/s15327957pspr1003_2 
people's ability to detect truth and lies. This meta-analysis, which included the veracity judgements made by almost 25,000 observers, revealed an average accuracy rate of 54\% in correctly classifying truth tellers and liars, barely above the chance level of $50 \%$. In theory, there are two possible explanations for such low accuracy rates. People perform poorly because (i) there is little difference between the truth tellers and liars they observe which makes the task very difficult, or (ii) they look for the wrong cues and fail to spot the differences that actually exist. In their meta-analysis, Hartwig and Bond ${ }^{22}$ examined these two possibilities and found support for the first explanation: People perform poorly because the differences between truth tellers and liars are too small to make the task achievable. This also explains why training people to detect lies - by informing them about "diagnostic nonverbal cues to deceit"- have hardly any effect. $^{23}$

Such research findings are criticized by professionals who claim that they are based on laboratory studies where the stakes (the negative consequences of getting caught or positive consequences of getting away with the lie) are lower than in the real-life situations professionals are interested in. They also claim that lies are easier to detect in high-stakes situations than in low-stakes situations. Research does not support this latter claim. In a meta-analysis, it was examined whether differences between truth tellers and liars differed between low- and high-

\footnotetext{
${ }^{22}$ Hartwig, M., \& Bond, C. F. (2011). Why do lie-catchers fail? A lens model meta-analysis of human lie judgments. Psychological Bulletin, 137, 643-659. Doi: 10.1037/a0023589

${ }^{23}$ Frank, M. G., \& Feeley, T. H. (2003). To catch a liar: Challenges for research in lie detection training. Journal of Applied Communication Research, 31, 58-75. Doi: 10.1080/00909880305377; Hauch, V., Sporer, S. L., Michael, S. W., \& Meissner, C. A. (2014). Does training improve the detection of deception? A meta-analysis. Communication Research published online 25 May 2014 Doi: $10.1177 / 0093650214534974$
} 
stakes situations. ${ }^{24}$ This was not the case. When the stakes are higher, liars may be more nervous and may be more likely to display signs of anxiety (which then can be interpreted as signs of deceit) but the same is true for truth tellers. They also become more nervous when the stakes increase and are therefore more likely to display signs of anxiety. In other words, raising the stakes has a similar effect on liars and truth tellers, which makes the difference between them not more pronounced than in low-stakes situations. ${ }^{25}$ In a well-known American police manual ${ }^{26}$ research is cited in which police detectives attempted to detect truths and lies in real life interviews with arsonists, rapists and murderers. ${ }^{27}$ Inbau et al. ${ }^{28}$ report that the accuracy rates were higher than typically found in laboratory research. This is true and accuracy rates of $65 \%$ were found. However, the (British) police detectives in that study relied more on speech than behavior. The research actually found a negative relationship between accuracy and paying attention to the nonverbal cues outlined in the Inbau et al. manual as "diagnostic cues to deceit," such as gaze aversion, making grooming gestures, and shifting position. The more the officers

\footnotetext{
${ }^{24}$ Hartwig, M., \& Bond, C. F. (2014). Lie detection from multiple cues: A meta-analysis. Applied Cognitive Psychology, 28, 661-667. Doi: 10.1002/acp.3052.

${ }^{25}$ Hartwig, M., \& Bond, C. F. (2014). Lie detection from multiple cues: A meta-analysis. Applied Cognitive Psychology, 28, 661-667. Doi: 10.1002/acp.3052.

${ }^{26}$ Inbau, F. E., Reid, J. E., Buckley, J. P., \& Jayne, B. C. (2013). Criminal interrogation and confessions, $5^{\text {th }}$ edition. Burlington, MA: Jones \& Bartlett Learning.

${ }^{27}$ Mann, S., Vrij, A., \& Bull, R. (2002). Suspects, lies and videotape: An analysis of authentic high-stakes liars. Law and Human Behavior, 26, 365-376. DOI: 10.1023/A:1015332606792

${ }^{28}$ Inbau, F. E., Reid, J. E., Buckley, J. P., \& Jayne, B. C. (2013). Criminal interrogation and confessions, $5^{\text {th }}$ edition. Burlington, MA: Jones \& Bartlett Learning.
} 
said to rely on such - in fact non-diagnostic - cues to deceit, the worse they performed in detecting lies.

\subsection{Factors Contributing to the Myth about the Strong Relationship Between Nonverbal Behavior and Deception}

The idea that nonverbal behavior is revealing about deception is a myth. Two factors probably contribute to this myth about the importance of nonverbal behavior in lie detection. First, people often overestimate the importance of nonverbal behavior in the exchange of information. Those who argue in favor of examining nonverbal cues to detect deceit often use quotes such as 'according to various social studies as much as $70 \%$ of a message communicated between persons occurs at a nonverbal level. ${ }^{29}$ We took this quote from a police manual. Other practitioners mention somewhat different percentages, but all commonly claim that nonverbal behavior is far more important in the exchange of information than verbal behavior. The social studies they refer to come from the psychologist Albert Mehrabian and published in his book Silent Messages. ${ }^{30}$ Mehrabian's research dealt with the communication of positive or negative emotions via single spoken words, like "dear" or "terrible." Obviously, if someone says little, verbal behavior cannot have much influence on the impression information. This does not mean that Mehrabian's findings can be applied to interview settings such as a courtroom, where witness-interviewees say considerably more than a single word. By Googling "Mehrabian" many links come up labelled "Mehrabian myths" and these links explain that Mehrabian's work is

\footnotetext{
${ }^{29}$ Inbau, F. E., Reid, J. E., Buckley, J. P., \& Jayne, B. C. (2013). Criminal interrogation and confessions, $5^{\text {th }}$ edition. Burlington, MA: Jones \& Bartlett Learning. The quote appears on page 122.

${ }^{30}$ Mehrabian, A. (1971). Silent messages, $1^{\text {st }}$ edition. Belmont, CA: Wadsworth.
} 
taken entirely out of context. Mehrabian himself shares that opinion, given the following quote: "I am obviously uncomfortable about misquotes of my work. From the very beginning I have tried to give people the correct limitations of my findings. Unfortunately the field of self-styled “corporate image consultants" or "leadership consultants" has numerous practitioners with very little psychological expertise" (31 October 2002).

The second factor that may contribute to the myth about the importance of nonverbal behavior in lie detection is the idea that behavior is more difficult to control than speech. Four factors contribute to this idea. ${ }^{31}$ First, there are certain automatic links between emotions and nonverbal behavior (e.g., the moment people become afraid, their bodies jerk backwards), whereas automatic links between emotions and speech content do not exist. Second, people are more practiced in using words than in using behavior, and this practice makes perfect. Third, people are more aware of what they are saying than of how they are behaving, and this awareness makes people better at controlling it. Fourth, verbally people can pause and think what to say, whereas nonverbally people cannot be silent. These reasons seem to underestimate the difficulty of telling a convincing and plausible lie and ignore that investigators can make lying verbally very difficult by using the right interview techniques. The next section will discuss four interview techniques that are effective to elicit verbal cues to deceit.

\subsection{Interviewing/Questioning to Detect Deception: Verbal Cues to Deceit}

When a person is being questioned or interviewed, lying is often more mentally taxing than truth telling which the person posing questions can exploit by making additional requests,

${ }^{31}$ DePaulo, B. M., \& Kirkendol, S. E. (1989). The motivational impairment effect in the communication of deception. In J. C. Yuille (Ed.), Credibility assessment (pp. 51-70). Dordrecht, the Netherlands: Kluwer. 
making it more difficult - affecting liars more than truth tellers, because liars have fewer cognitive abilities left over to deal with these additional requests. A good technique in this context is to ask the person, after giving his/her account in chronological order to do this subsequently in reverse order: "Could you tell us again what you did in the afternoon of March 22 2016, but now starting at the end of the afternoon and going backwards to the beginning of the afternoon?" This task is more challenging for liars than truth tellers and may result in liars making more contradictions than truth tellers do. (Therefore, the jury instruction that includes a credibility evaluation factor concerning whether the witness contradicted himself or herself, is valid.)

Asking the person to give the account in reverse order may also result in truth tellers providing more additional information than liars do. This reverse order technique is an effective technique when interviewing cooperative witnesses (truth tellers) as it makes them to think about the event again but this time from a different perspective, which often leads to additional information. In contrast, liars are concerned with 'consistency' and will try to report again what they have said before. This will not lead to additional information.

Truth tellers never say everything they know when invited to tell all they can remember, in part because this is not how people typically communicate (in daily interactions people give each other brief summaries of activities rather than detailed descriptions) and in part because people do not know what amount of detail is expected from them. ${ }^{32}$ An effective way to raise someone's expectations about how much detail is required is to provide them with a 'model

\footnotetext{
${ }^{32}$ Vrij, A., Hope, L., \& Fisher, R. P. (2014). Eliciting reliable information in investigative interviews. Policy Insights from Behavioral and Brain Sciences, 1, 129-136. Doi: 10.1177/2372732214548592
} 
statement', an example of a detailed account (about an event unrelated to the topic the interviewee is interviewed about to prevent them "copying" the text from the model statement). Truth tellers typically add more detail about the core event (the part of the event that matters) after the model statement than liars. Liars may find it mentally difficult to give additional detail (after all, it needs to sound plausible) but they may also be reluctant to say more out of fear that it will eventually reveal their lies. ${ }^{33}$

Liars prepare themselves for anticipated interrogation by preparing possible answers to questions they expect to be asked. ${ }^{34}$ This strategy has a limitation. It will be fruitful only if liars correctly anticipate which questions will be asked. This limitation can be exploited by asking questions that liars do not anticipate. Though liars can refuse to answer unexpected questions by saying "I don't know" or "I can't remember," such responses will create suspicion if these questions are about core aspects of the target event. A liar, therefore, has little option other than to fabricate a plausible answer on the spot, which is mentally taxing. One way that has proven to be successful in using the unexpected questions approach is by asking expected questions followed by unexpected questions. Liars are likely to have prepared answers to the expected questions and may therefore be able to answer them in considerable detail. However, they will not have prepared answers to the unexpected questions and may therefore struggle to generate detailed answers to them. For truth tellers the unexpected questions are equally unexpected but they do not

\footnotetext{
${ }^{33}$ Leal, S., Vrij, A., Warmelink, L., Vernham, Z., \& Fisher, R. (2015). You cannot hide your telephone lies: Providing a model statement as an aid to detect deception in insurance telephone calls. Legal and Criminological Psychology, 20, 129-146. Doi: 10.1111/lcrp.12017

${ }^{34}$ Hartwig, M., Granhag, P. A., \& Strömwall, L. (2007). Guilty and innocent suspects' strategies during police interrogations. Psychology, Crime, \& Law, 13, 213-227. Doi: 10.1080/10683160600750264
} 
find it more difficult to answer the unexpected questions than the expected questions and can answer them with similar ease and in similar detail. ${ }^{35}$

The Verifiability Approach is a fourth new approach which assists in detecting lies. Central to the Verifiability Approach are two assumptions. ${ }^{36}$ First, liars realize that providing many details is beneficial for them because detailed accounts are more likely to be believed. Second, liars prefer to avoid mentioning too many details out of fear that investigators can check such details and will discover that they are lying. A strategy that compromises these two conflicting motivations is to provide details that cannot be verified. Liars prefer to provide details that are difficult to verify (e.g., "Several people walked by when I sat there") and avoid providing details that are easy to verify (e.g., "I phoned my friend Zvi at 10.30 this morning). ${ }^{37}$ This difference in providing verifiable details between truth tellers and liars becomes more pronounced if interviewees first are asked "to provide details the investigator can check." Truth tellers then report details they did not think about before ("I think I saw a CCTV camera in that street, so you can check the footage," "I paid lunch with my credit card so my receipt will confirm that I was in that restaurant at that particular time"), whereas liars, by definition, cannot

\footnotetext{
${ }^{35}$ Lancaster, G. L. J., Vrij, A., Hope, L., \& Waller, B. (2012). Sorting the liars from the truth tellers: The benefits of asking unanticipated questions. Applied Cognitive Psychology, 27, 107-114. Doi: 10.1002/acp.2879; Warmelink, L., Vrij, A., Mann, S., Jundi, S., \& Granhag, P. A. (2012). Have you been there before? The effect of experience and question expectedness on lying about intentions. Acta Psychologica, 141, 178-183. Doi: 10.1016/j.actpsy.2012.07.011

${ }^{36}$ Nahari, G., Vrij, A., \& Fisher, R. P. (2014). Exploiting liars' verbal strategies by examining the verifiability of details. Legal and Criminological Psychology, 19, 227-239, Doi: 10.1111/j.20448333.2012.02069.x

${ }^{37}$ See for a review of this research: Vrij, A. \& Nahari, G. (in press). The Verifiability Approach In J. J. Dickinson, N. Schreiber Compo, R. N. Carol, B. L. Schwartz, \& M. R. McCauley (Eds.) Evidence-Based Investigative Interviewing. New York, U.S.A.: Routledge Press.
} 
provide checkable details. Verifiable detail include: (i) activities with identifiable or named persons who the interviewer can consult, (ii) activities that have been witnessed by identifiable or named persons who the interviewer can consult; (iii) activities that the interviewee believes may have been captured on CCTV; (iv) activities that may have been recorded through technology, such as using debit cards, mobile phones, or computers.

None of these proven approaches to evaluate credibility include considering nonverbal behavior but rather all involve carefully evaluating verbal behavior. As stated and discussed above, the concept that nonverbal behavior is a reliable factor to evaluate credibility is a myth.

\section{Conclusion}

Current well-accepted scientific studies support that human evaluation of a person's credibility based upon nonverbal behaviors such as manner and appearance is unreliable in determining believability, even when the determination is made by an expert. Jury instructions that advise a juror to base credibility determinations upon how a witness looked and acted while testifying are thus invalid. The legal community therefore should consider substantially revising jury instructions and craft more complete instructions to jurors by educating them that nonverbal cues have no connection to a witness's truthfulness or credibility. 


\section{APPENDIX A: Selected State Jury Instructions}

\section{Pennsylvania jury instructions on witness credibility:}

\section{Criminal 4.17 - "Credibility of Witnesses, General"}

1. As judges of the facts, you are sole judges of the credibility of the witnesses and their testimony. This means you must judge the truthfulness and accuracy of each witness's testimony and decide whether to believe all or part or none of that testimony. The following are some of the factors that you may and should consider when judging credibility and deciding whether or not to believe testimony:

a. Was the witness able to see, hear, or know the things about which [he] [she] testified?

b. How well could the witness remember and describe the things about which [he] [she] testified?

[c. Was the ability of the witness to see, hear, know, remember, or describe those things affected by youth, old age, or by any physical, mental, or intellectual deficiency?]

d. Did the witness testify in a convincing manner? [How did [he] [she] look, act, and speak while testifying? Was [his] [her] testimony uncertain, confused, selfcontradictory, or evasive?]

e. Did the witness have any interest in the outcome of the case, bias, prejudice, or other motive that might affect [his] [her] testimony?

f. How well does the testimony of the witness square with the other evidence in the case, including the testimony of other witnesses? [Was it contradicted or supported by the other testimony and evidence? Does it make sense?]

[g. [give other factors]].

[2. If you believe some part of the testimony of a witness to be inaccurate, consider whether the inaccuracy casts doubt upon the rest of his or her testimony. This may depend on whether he or she has been inaccurate in an important matter or a minor detail and on any possible explanation. For example, did the witness make an honest mistake or simply forget or did [he] [she] deliberately falsify?]

[3. While you are judging the credibility of each witness, you are likely to be judging the credibility of other witnesses or evidence. If there is a real, irreconcilable conflict, it is up to you to decide which, if any, conflicting testimony or evidence to believe.]

[4. As sole judges of credibility and fact, you, the jurors, are responsible to give the testimony of every witness, and all the other evidence, whatever credibility and weight you think it deserves.] 
Pa. SSJI (Crim) 4.17 (2016 $3^{\text {rd }}$ Ed.) (emphasis added).

\section{Civil 4.20 - "Believability of Witnesses Generally"}

As judges of the facts, you decide the believability of the witnesses' testimony. This means that you decide the truthfulness and accuracy of each witness's testimony and whether to believe all, or part, or none of each witness's testimony.

The following are some of the factors that you may and should consider when determining the believability of the witnesses and their testimony:

a. How well could each witness see, hear, or know the things about which he or she testified?

b. How well could each witness remember and describe those things?

c. Was the ability of the witness to see, hear, know, remember, or describe those things affected by age or any physical, mental, or intellectual disability?

d. Did the witness testify in a convincing manner? How did the witness look, act, and speak while testifying?

e. Was the witness's testimony uncertain, confused, self-contradictory, or presented in an evasive manner?

f. Did the witness have any interest in the outcome of this case, or any bias, or any prejudice, or any other motive that might have affected his or her testimony?

g. Was a witness's testimony contradicted or supported by other witnesses' testimony or other evidence?

h. Does the testimony make sense?

i. If you believe some part of the testimony of a witness to be inaccurate, consider whether that inaccuracy cast doubt upon the rest of that same witness's testimony. You should consider whether the inaccuracy is in an important matter or a minor detail.

You should also consider any possible explanation for the inaccuracy. Did the witness make an honest mistake or simply forget, or was there a deliberate attempt to present false testimony?

j. If you decide that a witness intentionally lied about a significant fact that may affect the outcome of the case, you may, for that reason alone, choose to disbelieve the rest of that witness's testimony. But, you are not required to do so.

k. As you decide the believability of each witness's testimony, you will at the same time decide the believability of other witnesses and other evidence in the case.

1. If there is a conflict in the testimony, you must decide which, if any, testimony you believe is true. 
As the only judges of believability and facts in this case, you, the jurors, are responsible to give the testimony of every witness, and all the other evidence, whatever weight you think it is entitled to receive.

Pa. SSJI (Civ) 4.20 (2017 $2^{\text {nd }}$ Ed.) (emphasis added)

Jury instruction sample excerpts for states that include a "nonverbal behavior factor" for evaluating credibility.

California (Criminal):

In evaluating a witness's testimony, you may consider anything that reasonably tends to prove or disprove the truth or accuracy of that testimony. Among the factors that you may consider are: ... What was the witness's behavior while testifying? ... What was the witness's attitude about the case or about testifying?

California Criminal Jury Instructions (CALCRIM) No. 266 (2018) (emphasis added), http://www.courts.ca.gov/partners/documents/calcrim_2018_edition.pdf.

Florida (Civil):

... In evaluating the believability of any witness and the weight you will give the testimony of any witness, you may properly consider the demeanor of the witness while testifying; the frankness or lack of frankness of the witness; the intelligence of the witness; any interest the witness may have in the outcome of the case; the means and opportunity the witness had to know the facts about which the witness testified; the ability of the witness to remember the matters about which the witness testified; and the reasonableness of the testimony of the witness, considered in the light of all the evidence in the case and in the light of your own experience and common sense.

Florida Standard Jury Instructions - Civil Cases, No. 601.2(a) (2018) (emphasis added), http://www.floridasupremecourt.org/civ jury instructions/instructions.shtml.

Massachusetts (Criminal):

... In deciding whether to believe a witness and how much importance to give a witness's testimony, you must look at all the evidence, drawing on your own common sense and experience of life. Often it may not be what a witness says, but how he says it that might give you a clue whether or not to accept his version of an event as believable. You may consider a witness's appearance and demeanor on the witness stand, his frankness or lack of frankness in testifying, whether his testimony is reasonable or unreasonable, probable or improbable. 
Massachusetts Criminal Model Jury Instructions for Use in the District Court, No. 2.260 (2017) (emphasis added), https://www.mass.gov/files/documents/2016/11/vc/2260credibility-of-witnesses.pdf. 